\title{
UCRL-TR-230686
}

LAWRENCE LIVERMORE NATIO N A L LABORATORY
Re-evaluation of the 1995 Hanford Large Scale Drum Fire Test Results

J. M. Yang

May 3, 2007 
This document was prepared as an account of work sponsored by an agency of the United States Government. Neither the United States Government nor the University of California nor any of their employees, makes any warranty, express or implied, or assumes any legal liability or responsibility for the accuracy, completeness, or usefulness of any information, apparatus, product, or process disclosed, or represents that its use would not infringe privately owned rights. Reference herein to any specific commercial product, process, or service by trade name, trademark, manufacturer, or otherwise, does not necessarily constitute or imply its endorsement, recommendation, or favoring by the United States Government or the University of California. The views and opinions of authors expressed herein do not necessarily state or reflect those of the United States Government or the University of California, and shall not be used for advertising or product endorsement purposes.

This work was performed under the auspices of the U.S. Department of Energy by University of California, Lawrence Livermore National Laboratory under Contract W-7405-Eng-48. 


\section{Re-evaluation of the 1995 Hanford Large-Scale Drum Fire Test Results}

A large-scale drum performance test was conducted at the Hanford Site in June 1995, in which over one hundred (100) 55-gal drums in each of two storage configurations were subjected to severe fuel pool fires. The two storage configurations in the test were pallet storage and rack storage. The description and results of the large-scale drum test at the Hanford Site were reported in WHC-SD-WM-TRP-246, "Solid Waste Drum Array Fire Performance," Rev. 0, 1995. This was one of the main references used to develop the analytical methodology to predict drum failures in WHC-SD-SQA-ANAL-501, "Fire Protection Guide for Waste Drum Storage Array," September 1996.

Three drum failure modes were observed from the test reported in WHC-SD-WM-TRP-246. They consisted of seal failure, lid warping, and catastrophic lid ejection. There was no discernible failure criterion that distinguished one failure mode from another. Hence, all three failure modes were treated equally for the purpose of determining the number of failed drums. General observations from the results of the test are as follows:

- Trash expulsion was negligible.

- Flame impingement was identified as the main cause for failure.

- The range of drum temperatures at failure was $600^{\circ} \mathrm{C}$ to $800^{\circ} \mathrm{C}$. This is above the yield strength temperature for steel, approximately $540^{\circ} \mathrm{C}\left(1,000^{\circ} \mathrm{F}\right)$.

- The critical heat flux required for failure is above $45 \mathrm{~kW} / \mathrm{m}^{2}$.

- Fire propagation from one drum to the next was not observed.

The statistical evaluation of the test results using, for example, the student's $t$-distribution, will demonstrate that the failure criteria for TRU waste drums currently employed at nuclear facilities are very conservative relative to the large-scale test results. Hence, the safety analysis utilizing the general criteria described in the five bullets above will lead to a technically robust and defensible product that bounds the potential consequences from postulated fires in TRU waste facilities, the means of storage in which are the Type A, 55-gal drums. 


\subsection{Introduction}

A large-scale drum performance test was conducted at the Hanford Site in June 1995, in which over one hundred (100) 55-gal drums in each of two storage configurations were subjected to severe fuel pool fires. The two storage configurations in the test were pallet storage and rack storage. The description and results of the large-scale drum test at the Hanford Site were reported in WHC-SD-WM-TRP-246, "Solid Waste Drum Array Fire Performance," Rev. 0, 1995 (Reference 1).

Three drum failure modes were observed from the test reported in WHC-SD-WM-TRP-246. They consisted of seal failure, lid warping, and catastrophic lid ejection. There was no discernible failure criterion that distinguished one failure mode from another. In addition, there was no discernible correlation in the failure data among the location, heat flux, temperature, and pressure.

A statistical analysis on the failure data was not performed in WHC-SD-WM-TRP-246. Hence, the failure data in WHC-SD-WM-TRP-246 are re-examined in this paper to determine the degree of conservatism associated with the safety analysis commonly performed on TRU waste storage facilities in DOE/EM. Re-examination of the data in WHC-SD-WM-TRP-246 is mainly focused on the pallet storage configuration, which is the predominant storage configuration in the DOE/EM complex. In particular, a statistical analysis, based on the Student's $t$-distribution, is performed to estimate the conservative failure criteria for the heat flux and the temperature when subjected to a severe fuel pool fire.

\subsection{The Hanford large-scale drum fire test}

A large-scale drum performance test was conducted at the Hanford Site in June 1995, in which more than one hundred (100) 55-gal drums in each of two storage configurations were subjected to severe fuel pool fires. The two storage configurations in the test were pallet storage and rack storage. This test was a continuation in a series of tests, which were small scale and involved only a few drums, performed at SNL, LLNL, and INEEL. The summary of these tests is provided in Appendix A to WHC-SD-WM-TRP-233, "Analytical and Experimental Evaluation of Solid Waste Drum Array Fire Performance,” Rev. 0, 1995.

The description and results of the large-scale drum test at the Hanford Site were reported in WHC-SD-WM-TRP-246, "Solid Waste Drum Array Fire Performance," Rev. 0, 1995 (Reference 1). This was one of the main references used to develop the analytical methodology to predict drum failures in WHC-SD-SQA-ANAL-501, "Fire Protection Guide for Waste Drum Storage Array," September 1996. The analytical approach in WHC-SD-SQA-ANAL-501 is in turn used to perform the accident analysis involving TRU waste drums in the DOE/EM complex.

Three drum failure modes were observed from the test reported in WHC-SD-WM-TRP-246. They consisted of seal failure, lid warping, and catastrophic lid ejection. There was no discernible failure criterion that distinguished one failure mode from another. Hence, all three failure modes were treated equally for the purpose of determining the number of failed drums.

General observations from the results of the test are as follows:

- Trash expulsion was negligible.

- Flame impingement was identified as the main cause for failure. 
- The range of drum temperatures at failure was $600^{\circ} \mathrm{C}$ to $800^{\circ} \mathrm{C}$.

- The critical heat flux required for failure is above $45 \mathrm{~kW} / \mathrm{m}^{2}$.

- Fire propagation from one drum to the next was not observed.

A complete set of the measured data from the large-scale fire tests for rack storage and pallet storage configurations is excerpted and summarized in Table 1 at the end of the document. The test results for the two drum storage configurations are summarized below.

\subsection{Pallet storage test}

Of the twenty-two failed drums that failed in one of the three failure modes, only seven drums were instrumented and yielded the failure flux data. For those seven drums, the measured radiant heat flux at failure ranged from $77 \mathrm{~kW} / \mathrm{m}^{2}$ to $200 \mathrm{~kW} / \mathrm{m}^{2}$. The measured temperature at failure ranged from $526^{\circ} \mathrm{C}$ to $951{ }^{\circ} \mathrm{C}$. Observations and recommendations for the pallet storage test in Reference 1 are as follows:

- A total of 135 liters (36 gal) of diesel was used that was spread over an area of $9.3 \mathrm{~m}^{2}$. In addition, 9.5 gal of gasoline was added to ensure even combustion.

- 144 drums on pallets, four drums on a pallet, were stacked three-level high.

- The magnitude of the fire was $14.5 \mathrm{MW}$ lasting approximately 5 minutes.

- Of the 144 drums, there were 24 drums directly inside the fuel pool as shown in Figure 1. Fourteen of the twenty-four (24) drums engulfed in the fuel pool fire failed.

- The total number of failed drums, including those with failed seals, was twenty-two (22) as shown in Tables 9 and 11 of WHC-SD-WM-TRP-246. This represents a 15\% (22/144) failure rate.

- Only three drums, two in the fuel pool fire at the bottom two tiers and one adjacent to the fire at the bottom tier, failed by lid ejection. Of the remaining nineteen (19) failed drums, seal failure occurred in eleven drums ( $50 \%$ of the total failure).

Seven of the twenty-two failed drums in the pallet storage configuration were located outside the fuel pool fire. For the two failed drums with low measured temperatures at failure below $600^{\circ} \mathrm{C}$, failure occurred well after the fuel pool fire was extinguished. Failure times were 363 seconds and 763 seconds at $538^{\circ} \mathrm{C}$ and $526^{\circ} \mathrm{C}$ for $\mathrm{O} 831$ and $\mathrm{O} 743$, respectively. The measured temperature and pressure for the failed drums on pallets are graphically shown in Figure 2. A histogram of the failure temperature data is shown in Figure 3.

\subsection{Rack storage test}

The total failure rate in the rack storage test is higher because of the increased fire severity. The magnitudes of the rack storage test fire is $25.6 \mathrm{MW}$, higher than $14.5 \mathrm{MW}$ in the pallet storage test. The measured temperature at failure ranged from $339^{\circ} \mathrm{C}$ to $760^{\circ} \mathrm{C}$. For the seven drums, the measured radiant heat flux at failure ranged from $64 \mathrm{~kW} / \mathrm{m}^{2}$ to $165 \mathrm{~kW} / \mathrm{m}^{2}$. Observations in Reference 1 are as follows:

- A total of 265 liters (70 gal) of diesel was spread over an area of $16.6 \mathrm{~m}^{2}$. In addition, 5 gal of gasoline was added to ensure even combustion. 
Figure 1. Pallet storage array fire test (Figure 6, Reference 1).
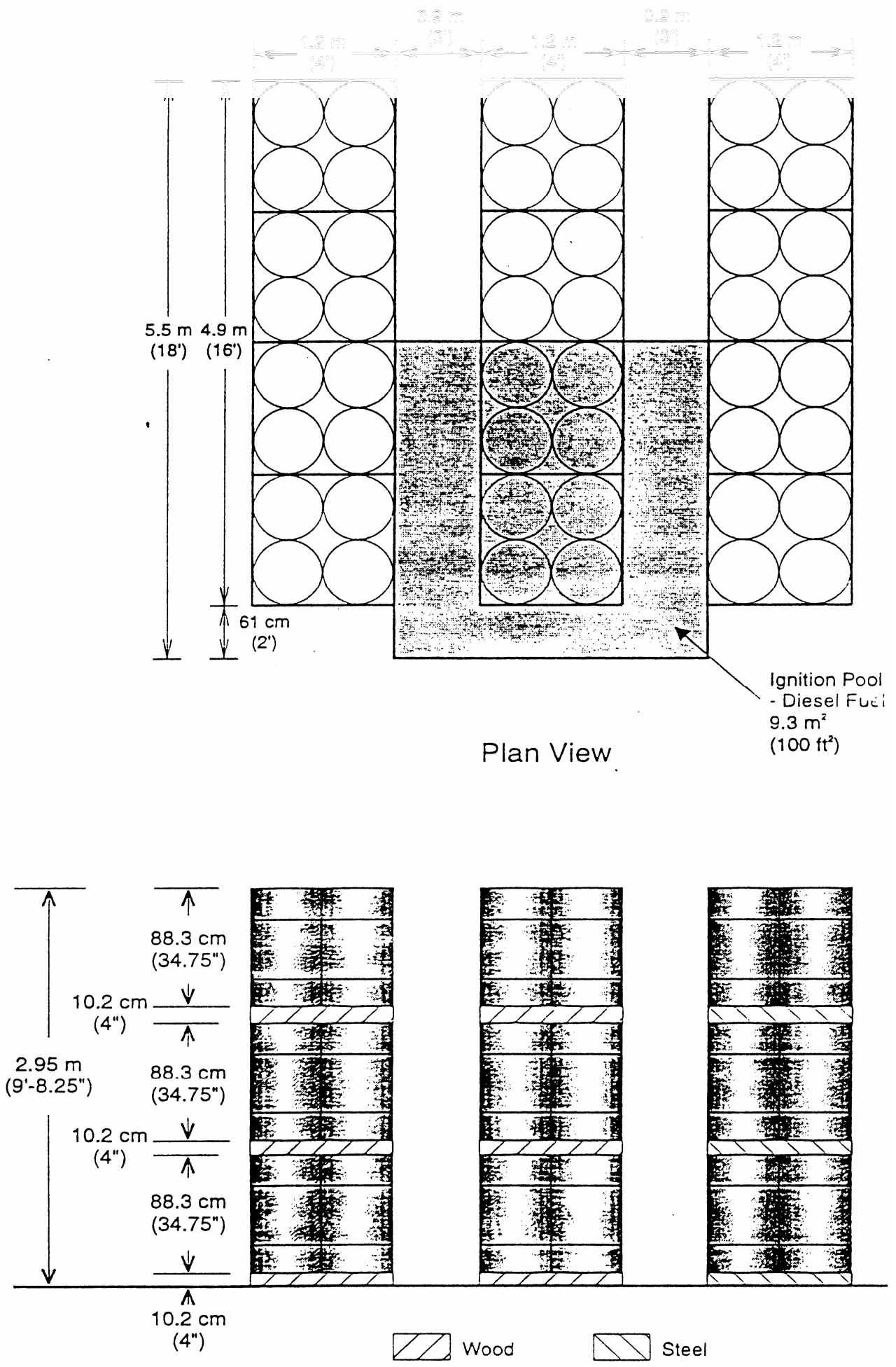

Side View 
Figure 2. Pallet storage array fire test data.

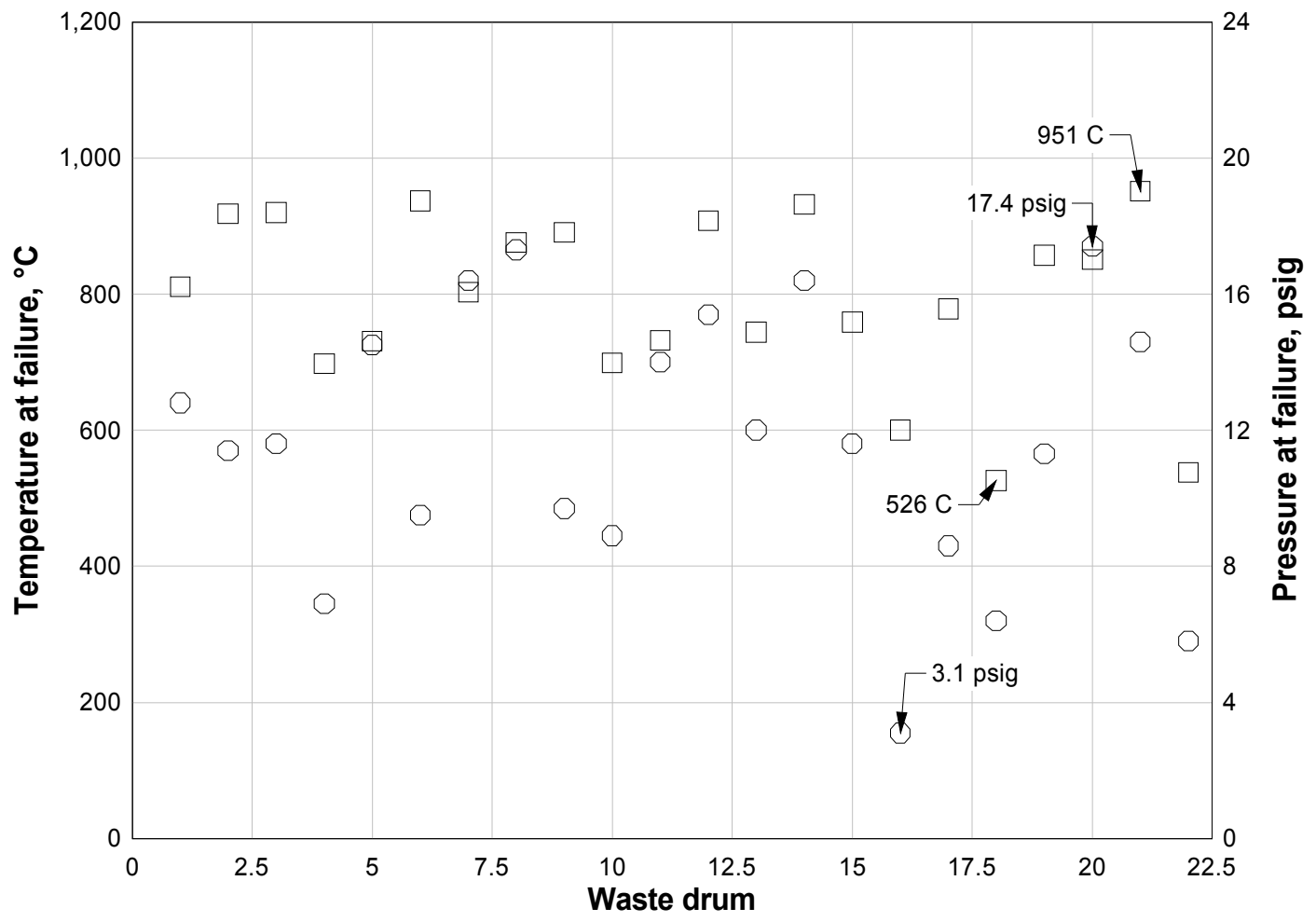

- The magnitude of the fire was $25.9 \mathrm{MW}$ lasting approximately 5 minutes.

- 144 drums in racks were arranged in six levels high.

- The text in Section 8.2.1 and Section 8.2.2, consistent with those in Figure 58 and Table 12, in WHC-SD-WM-TRP-246 states that a total of 37 drums failed. The number of failures also includes those due to seal failures. The resultant failure rate is $26 \%(37 / 144)$.

- 48 drums of the 144 drums were directly in the fuel pool fire, of which 35 drums failed.

Six instrumented drums in the rack storage configuration located outside the fuel pool did not fail. Of those, four instrumented drums-X251, X253, X254, and X352 - located outside the fuel pool fire provided the heat flux data. The measured heat flux ranged from $23 \mathrm{~kW} / \mathrm{m}^{2}$ to $37 \mathrm{~kW} / \mathrm{m}^{2}$. The data associated with these drums that did not fail can provide additional assurance that the selected failure criterion for the heat flux is reasonable. Also, it appears that data for few of the failed drums are not provided in Reference 1.

The increased number of 37 failures in the rack storage test may be due to the increased magnitude of the fire. For both pallet and rack storage tests, the predicted failure rates prior to the tests were higher, at 48/144 and 45/144, respectively, than the test data as shown in Table 12 in Reference 1. While the fraction of failed drums engulfed in the fuel pool fire is higher at $64 \%$ (46/72), flooding a nuclear facility with gasoline or diesel is not credible. It would take a total of 410 gal of gasoline to flood a $40-\mathrm{ft} \times 40-\mathrm{ft}$ compartment to sustain a fire for 140 seconds. Hence, the failure rate of engulfed drums alone, which is higher, is not likely to be relevant for evaluating accident conditions in a TRU waste storage facility. 
Figure 3. Distribution of the number of failed drums at measured temperature with an interval of $50^{\circ} \mathrm{C}$ from the pallet storage data.

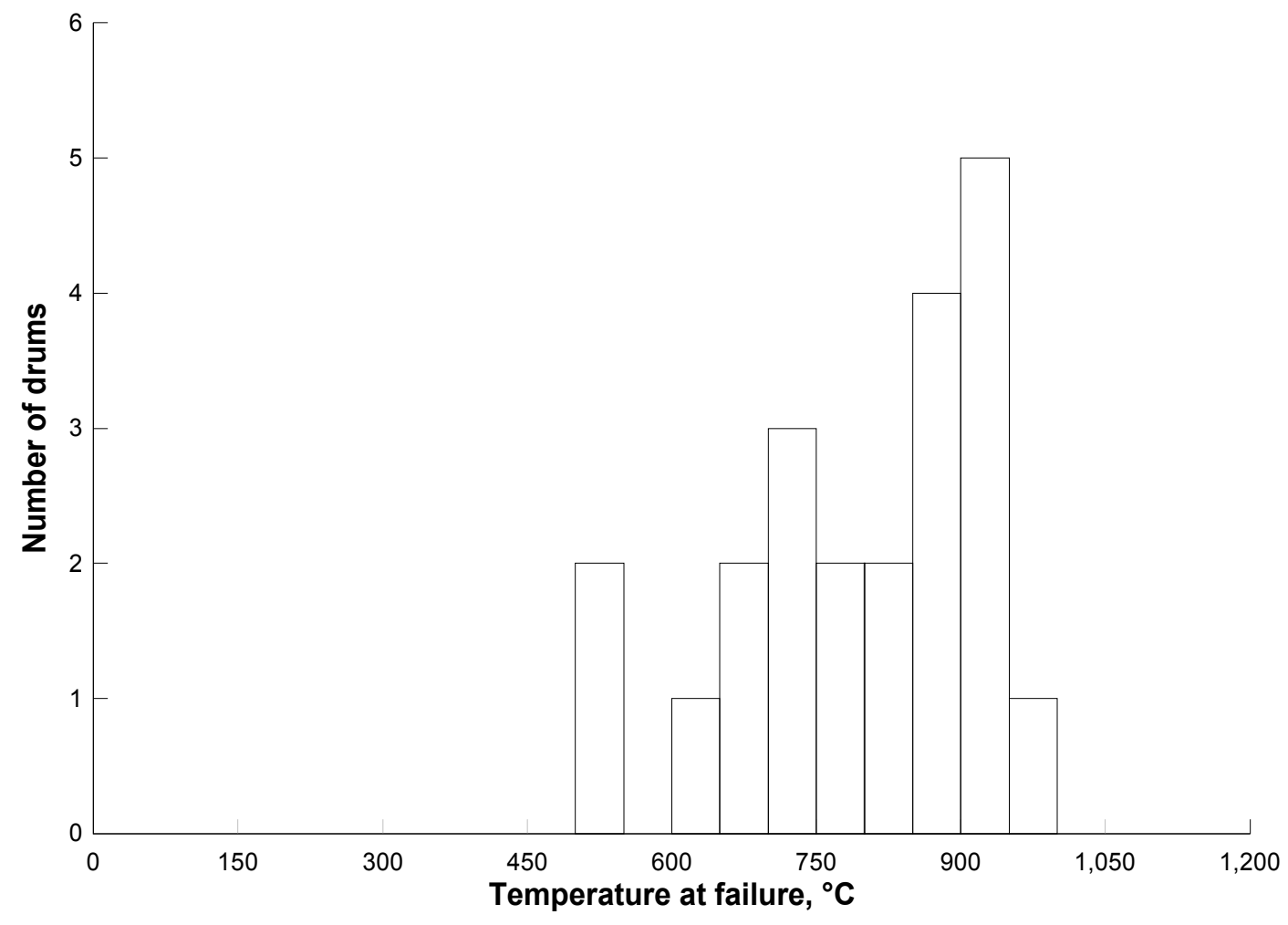

\subsection{Analysis using Student's t-distribution}

A statistical distribution published by William Gosset in 1908. His employer, Guinness Breweries, required him to publish under a pseudonym, so he chose "Student." Given $N$ independent measurements $x_{i}$, let

$$
t \equiv \frac{\bar{x}-\mu}{s / \sqrt{N}} \Rightarrow \mu=\bar{x} \pm t s / \sqrt{N}
$$

where $\mu$ is the population mean, $\bar{x}$ is the sample mean, and $s$ is the estimator for the unknown population standard deviation, $\sigma$, or simply the sample standard deviation. The sample standard deviation is calculated from the sample variance, as follows:

$$
s^{2}=\frac{1}{N-1} \sum_{i=1}^{N}\left(x_{i}-\bar{x}\right)^{2}
$$

The Student's $t$-distribution is defined as the distribution of the random variable $t$ that is (very loosely) the "best" estimate without knowing $\sigma$. The Student's $t$-distribution assumes that the general population, from which the sample is drawn, is normally distributed. Based on Equation 1, the upper and lower limits of the true population mean, $\mu$, can be estimated as follows: 


$$
\bar{x}-t s / \sqrt{N} \leq \mu \leq \bar{x}+t s / \sqrt{N}
$$

The standard error of the mean of a sample from a population is the standard deviation of the sampling distribution of the mean, and may be estimated by the formula:

$$
S_{E}=\frac{s}{\sqrt{N}}
$$

where $s$ is an estimate of the standard deviation, $\sigma$, of the population. $N$ is the sample size.

Using data in Table 1, the sample mean, the sample variance, and the sample standard deviation of the temperature at failure, $\bar{x}, s^{2}$, and $s$, are $793.6^{\circ} \mathrm{C}, 16,054$, and $126.7^{\circ} \mathrm{C}$, respectively. The standard error of the sample mean, $S_{E}$, is 27.01. Results of the statistical analysis for the pallet storage test are shown in Table 2.

Table 2. Statistical analysis results of the measured drum temperature at failure based on the

\begin{tabular}{|c|c|c|c|c|c|}
\hline & Drum No. & $\begin{array}{l}\text { Temperature at } \\
\text { failure, }{ }^{\circ} \mathrm{C}\end{array}$ & $\begin{array}{l}\text { theat flux at } \\
\mathrm{e}, \mathrm{kW} / \mathrm{m}^{2}\end{array}$ & $\left(x_{i}\right.$ & \\
\hline 1 & 0831 & 538 & 85 & 65350 & 2070 \\
\hline 2 & 0813 & 951 & NM & 24763 & NC \\
\hline 3 & 0812 & 851 & NM & 3291 & NC \\
\hline 4 & 0811 & 857 & NM & 4015 & NC \\
\hline 5 & 0743 & 526 & NM & 71629 & $\mathrm{NC}$ \\
\hline 6 & $\mathrm{O} 742$ & 778 & NM & 244.5 & $\mathrm{NC}$ \\
\hline 7 & 0741 & 600 & NM & 37495 & NC \\
\hline 8 & $\mathrm{O} 723$ & 759 & NM & 1200 & $\mathrm{NC}$ \\
\hline 9 & O722 & 932 & NM & 19144 & $\mathrm{NC}$ \\
\hline 10 & 0721 & 744 & NM & 2464 & $\mathrm{NC}$ \\
\hline 11 & 0713 & 908 & NM & 13079 & $\mathrm{NC}$ \\
\hline 12 & O711 & 732 & NM & 3799 & NC \\
\hline 13 & 0641 & 699 & 77 & 8956 & 2862 \\
\hline 14 & $\mathrm{O} 633$ & 891 & 81 & 9480 & 2450 \\
\hline 15 & 0632 & 876 & 135 & 6784 & 20.25 \\
\hline 16 & O631 & 803 & 166 & 87.68 & 1260 \\
\hline 17 & O612 & 937 & NM & 20553 & $\mathrm{NC}$ \\
\hline 18 & 0611 & 731 & NM & 3923 & $\mathrm{NC}$ \\
\hline 19 & 0541 & 698 & NM & 9146 & NC \\
\hline 20 & 0533 & 920 & 124 & 15968 & 42.25 \\
\hline 21 & 0532 & 918 & 176 & 15466 & 2070 \\
\hline 22 & 0521 & 811 & 200 & 301.5 & 4830 \\
\hline \multicolumn{4}{|c|}{ sample mean, $\bar{x}$} & 793.6 & 130.5 \\
\hline \multicolumn{4}{|c|}{ sample size, $N$} & 22 & 8 \\
\hline \multicolumn{4}{|c|}{ sample variance, $s^{2}$} & 16054 & 2229 \\
\hline \multicolumn{4}{|c|}{ sample standard deviation, $s$} & 126.7 & 47.22 \\
\hline
\end{tabular}
Student's t-distribution. 
From Appendix D in Reference 4, the value of $t$ for a sample size of 22, i.e., the degree of freedom of 21 , with the $95 \%$ confidence level is 2.08 . The estimate of the lower limit of the population mean, $\mu$, of the temperature is then:

$$
\mu \geq \bar{x}-t s / \sqrt{N}=\bar{x}-S_{E} t=793.6-126.7 / \sqrt{22} \times 2.08=737.5
$$

Similarly, the value of $t$ for a sample size of 8 and the estimate of the lower limit of the mean heat flux at failure at the $99 \%$ confidence level are 3.499 and $72.08 \mathrm{~kW} / \mathrm{m}^{2}$, respectively. Results of the statistical analysis for the measured temperature and heat flux data at failure for the two storage configurations at 95\% and 99\% confidence intervals are summarized in Tables 3 and 4, respectively.

Table 3. Statistical analysis results of the measured drum temperature at failure based on the Student's $t$-distribution.

\begin{tabular}{|l|rrrrr|}
\hline & $\begin{array}{c}\text { Sample } \\
\text { mean }\end{array}$ & $\begin{array}{c}\text { Standard error } \\
\text { of the mean }\end{array}$ & Sample size & $\begin{array}{c}\text { Lower limit of the } \\
\text { mean at 95\% CL }\end{array}$ & $\begin{array}{r}\text { Lower limit of the } \\
\text { mean at 99\% CL }\end{array}$ \\
\hline Pallet storage & 793.6 & 27.01 & 22 & 737.5 & 717.2 \\
Rack storage & 588.2 & 30.02 & 17 & 524.5 & 500.5 \\
Combined & 704.1 & 25.81 & 39 & 651.8 & 634.1 \\
\hline
\end{tabular}

Table 4. Statistical analysis results of the measured heat flux at failure based on the Student's t-distribution.

\begin{tabular}{|l|rrrrr|}
\hline & $\begin{array}{c}\text { Sample } \\
\text { mean }\end{array}$ & $\begin{array}{c}\text { Standard error } \\
\text { of the mean }\end{array}$ & Sample size & $\begin{array}{c}\text { Lower limit of the } \\
\text { mean at 95\% CL }\end{array}$ & $\begin{array}{r}\text { Lower limit of the } \\
\text { mean at 99\% CL }\end{array}$ \\
\hline Pallet storage & 130.5 & 16.69 & 8 & 91.03 & 72.08 \\
Rack storage & 101.8 & 10.67 & 11 & 78.05 & 68.02 \\
Combined & 113.9 & 9.662 & 19 & 93.59 & 86.08 \\
\hline
\end{tabular}

\subsection{Results and discussion}

The adiabatic flame temperature from complete combustion of a stoichiometric air-octane mixture under ideal conditions was computed using Cheetah 2.0 (Reference 8) to confirm the experimental observation that flame impingement is the main cause for drum failure. Gasoline is octane with oxygenate or additives to reduce pollution. For simplicity, combustion of a stoichiometric octane-air mixture is shown below:

$$
\mathrm{C}_{8} \mathrm{H}_{18}+12.5\left[\begin{array}{c}
\mathrm{O}_{2} \\
3.76 \mathrm{~N}_{2}
\end{array}\right] \Rightarrow 8 \mathrm{CO}_{2}+9 \mathrm{H}_{2} \mathrm{O}+47 \mathrm{~N}_{2}
$$

The computed adiabatic flame temperature is $2,238^{\circ} \mathrm{K}\left(1,965^{\circ} \mathrm{C}\right.$, Reference 2$)$. A fuel pool fire would be rich in fuel, as evidenced by black smoke in most fuel pool fires, leading to a lower flame temperature. For example, an equivalence ratio of 2, i.e., twice as much fuel in the mixture as that in the stoichiometric mixture, yielded an adiabatic flame temperature of $1,512^{\circ} \mathrm{K}$ 
$\left(1,238^{\circ} \mathrm{C}\right)$. Even for a rich mixture, computed flame temperatures would indicate a significant thermal stress on the structural integrity of drums and appear to confirm that flame impingement is the main cause of the drum failure.

Figure 3-11.11 in Reference 3 shows a decreasing trend of the average emissive power with increasing diameters of fuel pool fires in open air. Data in Table 3-11.4 in Reference 3 show a wide range of measured emissive powers from $10 \mathrm{~kW} / \mathrm{m}^{2}$ for smoky fires to $280 \mathrm{~kW} / \mathrm{m}^{2}$. The average flame emissive power, $\dot{q}_{f l}^{\prime \prime}$, is computed using the equation below (Reference 3 ):

$$
\dot{q}_{f l}^{\prime \prime}=140 \times \exp \left\{-0.12 \times D_{e q}\right\}+20 \times\left(1-\exp \left\{-0.12 \times D_{e q}\right\}\right)
$$

The equivalent diameter of the $100-\mathrm{ft}^{2}$ diesel fuel pool is $3.44 \mathrm{~m}$. The calculated flame emissive power of the fire in the large-scale fire test is $99 \mathrm{~kW} / \mathrm{m}^{2}$, consistent with the calculated results in Reference 1. The flame emissive power also appears to confirm that flame impingement is the main cause for failure.

\subsection{Analysis of the combined test data}

The sample size of the failed drums is relatively small even in the large scale fire test. There is also uncertainty associated with the assumed distribution of the failure data as presented in Figure 3 for the pallet storage configuration alone. It is therefore prudent to examine the combined failure data to derive the failure criteria for drums when subjected to a severe fuel pool fire. It is also prudent to use the $99 \%$ confidence level results because even the combined sample size is relatively small. The combined failure data are shown in Figure 4. Histograms of the heat flux and temperature at failure are shown in Figure 5 and Figure 6 at the end of the document, respectively.

The lower estimate of the heat flux at failure for a large population of drums on pallet when subjected to a severe fire is above $72 \mathrm{~kW} / \mathrm{m}^{2}$ with the $99 \%$ confidence level. In comparison, the lower estimate of the heat flux at failure for a large population of drums when subjected to a severe fire is above $68 \mathrm{~kW} / \mathrm{m}^{2}$ with the $99 \%$ confidence level for the rack storage. Both are clearly above $45 \mathrm{~kW} / \mathrm{m}^{2}$, commonly used as the failure criterion in the DOE/EM complex, as observed in Reference 1.

Because the magnitude of the fire in the rack storage test is greater than that of the pallet storage test, the difference in the mean values at failure may be statistically significant. To confirm this hypothesis, mean values of the heat flux and temperature at failure from the two storage configurations in the large-scale fire are tested. First, the heat flux data are tested from the two storage configurations, as follows:

$$
s_{\bar{x}_{1}-\bar{x}_{2}}=\sqrt{\frac{s_{1}^{2}}{N_{1}}+\frac{s_{2}^{2}}{N_{2}}}=\sqrt{\frac{2,229}{8}+\frac{1,251}{11}}=19.81
$$

Second, the $Z$ value for the two tailed test is calculated to determine whether the difference in the two means is significant, as follows:

$$
Z=\frac{\bar{x}_{1}-\bar{x}_{2}}{S_{\bar{x}_{1}-\bar{x}_{2}}}=\frac{130.5-101.8}{19.81}=1.448 \leq 1.96<2.576
$$


The result indicates that the difference between the two mean values is due to chance at a level of significance of $0.05\left(t_{\infty}= \pm 1.96\right.$ from Appendix D in Reference 4) and $0.01\left(t_{\infty}= \pm 2.576\right)$. Stated otherwise, the difference in the mean heat flux at failure is not sensitive to the storage configuration and the magnitude of the fire. Further, based on the statistical analysis, a better estimate of the conservative heat flux criterion for failure of TRU waste drums when subjected to a severe fire is $68 \mathrm{~kW} / \mathrm{m}^{2}$ with the $99 \%$ confidence level. This is above $45 \mathrm{~kW} / \mathrm{m}^{2}$ as observed in Reference 1.

As mentioned previously, there were four drums in the rack storage test-X251, X253, X254, and X352 - located outside the fuel pool fire with measured heat flux data that did not fail. The measured heat flux ranged from $23 \mathrm{~kW} / \mathrm{m}^{2}$ to $37 \mathrm{~kW} / \mathrm{m}^{2}$. The data associated with these drums that did not fail provide additional assurance that the selected failure criterion for the heat flux is reasonable.

For the pallet storage configuration alone, the lower estimate of the temperature at failure for a large population of drums when subjected to a severe 14.5 -MW fuel pool fire is above $717^{\circ} \mathrm{C}$ with the $99 \%$ confidence level. This is clearly well within the failure temperature range of $600^{\circ} \mathrm{C}$ to $800^{\circ} \mathrm{C}$ stated in Reference 1 .

For the rack storage configuration alone, however, the lower estimate of the temperature at failure for a large population of drums when subjected to a severe 25.9-MW fuel pool fire is above $500^{\circ} \mathrm{C}$ with the $99 \%$ confidence level. This is out of the failure temperature range discussed in Reference 1 . Hence, the difference in mean values may be statistically significant.

Figure 4. Combined pallet storage and rack storage fire test data.

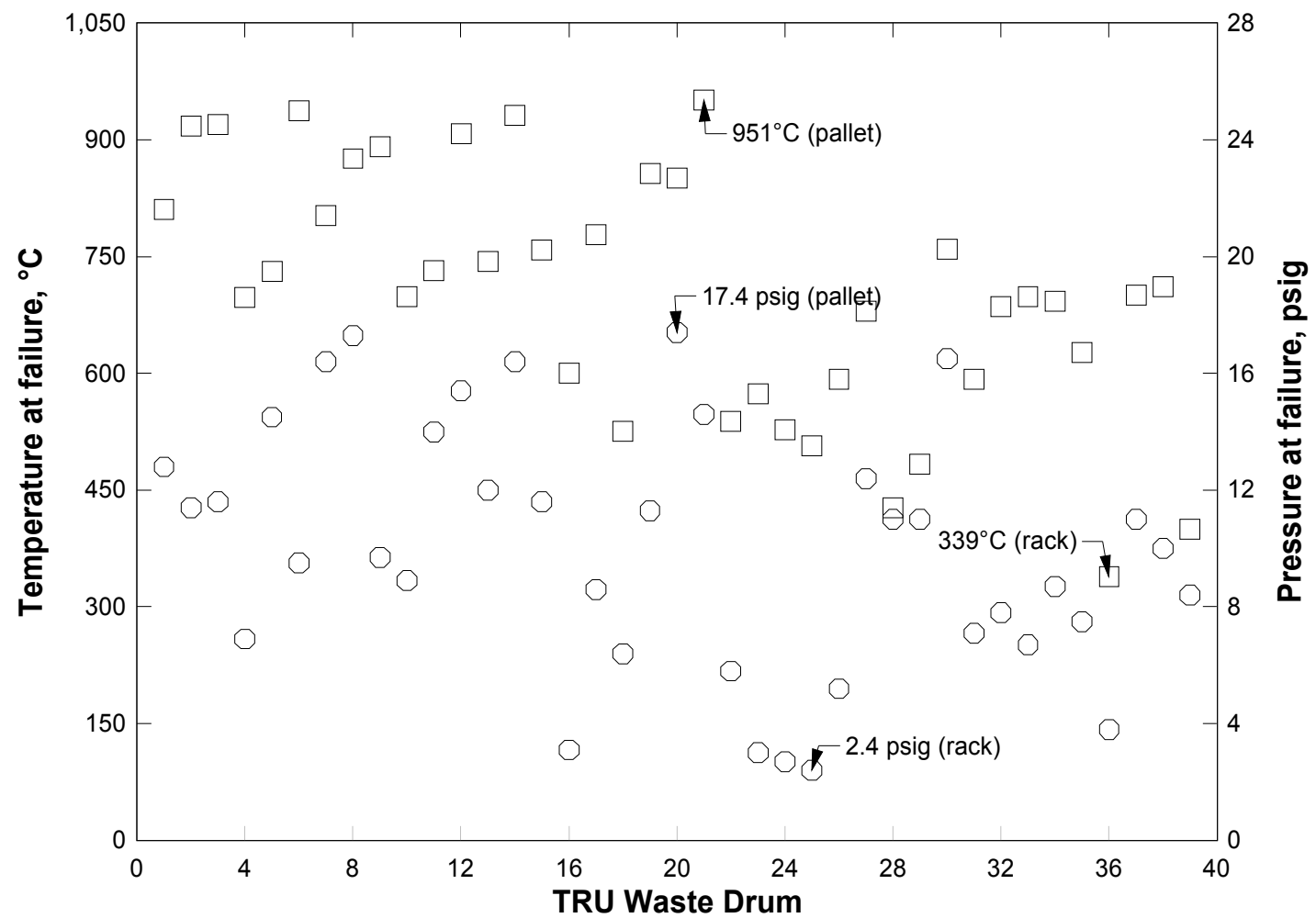


To test the hypothesis on the failure temperature, mean values from the two tests are tested:

$$
\sigma_{\bar{x}_{1}-\bar{x}_{2}}=\sqrt{\frac{\sigma_{1}^{2}}{N_{1}}+\frac{\sigma_{2}^{2}}{N_{2}}}=\sqrt{\frac{16,054}{22}+\frac{15,318}{17}}=40.38
$$

Again, the $Z$ value for the two tailed test is calculated to determine whether the difference in the two means is statistically significant, as follows:

$$
Z=\frac{793.6-588.2}{40.38}=5.088 \geq 2.576>1.96
$$

The calculated value of $Z$ is greater than 1.96 and 2.576, which indicates that the difference between the two mean values is statistically significant at a level of significance of 0.05 $\left(t_{\infty}= \pm 1.96\right)$ and $0.01\left(t_{\infty}= \pm 2.576\right)$. The test data do not allow a separate analysis to distinguish the effect of the magnitude of the test fire and the effect of the storage configuration. It is inferred that the temperature at failure is sensitive to the magnitude of the fire and, to a lesser extent, the storage configuration.

\subsection{Effect of steel pallet}

Little known or analyzed in the large scale drum fire test is the effect of the steel pallet on the drum failure in a fuel pool fire. One third of the drums in the pallet storage test was stored on steel pallets. These were on Rows 4 and 5. Of the 48 drums stored on steel pallets, only four drums failed: O521, O532, O533, and O541. Of the 48 drums stored on wooden pallets outside the fuel pool, only four drums failed: O831, O813, O812, and O811. The results are not statistically significant to be conclusive.

Although the benefit of the steel pallet is not apparent from the large scale test data, it is generally a good practice to maintain the combustible loading in TRU waste storage facilities at a low level. This is consistent with the recommendation in Section 8.2.2 in Reference 1.

\subsection{Conclusion and recommendations}

The sample size of the failed drums is relatively small even in the large scale fire test. Consequently, there is uncertainty associated with the assumed distribution of the failure data. As a result, it is prudent to establish conservative failure criteria for TRU waste storage. For added assurance, the failure criteria with a 99\% confidence interval are recommended and used. In general, recommended failure criteria derived from on the statistical analysis compare favorably with the observations and recommendations in Reference 1. They are discussed as follows:

- Trash expulsion was negligible.

- Flame impingement is the main cause for failure.

The calculated flame emissive power of the fire in the large-scale fire test is $99 \mathrm{~kW} / \mathrm{m}^{2}$. The calculated adiabatic flame temperature for octane (a substantial constituent of gasoline) with an equivalence ratio of 2 , i.e., twice as much fuel in the mixture as that in the stoichiometric mixture, is $1,512^{\circ} \mathrm{K}\left(1,238^{\circ} \mathrm{C}\right)$. The calculated adiabatic flame temperature and the flame emissive power appear to confirm that flame impingement is the main cause for failure. 
- The range of drum temperatures at failure was $600^{\circ} \mathrm{C}$ to $800^{\circ} \mathrm{C}$.

The test data do not allow a separate analysis to distinguish the effect of the magnitude of the test fire and the effect of the storage configuration. It is inferred from the analysis that the temperature at failure is sensitive to the magnitude of the fire and, to a lesser extent, the storage configuration. For TRU waste drums on pallets subjected to a severe fire with a magnitude equal to or less than $14.5 \mathrm{MW}$, the recommended failure criterion is $700^{\circ} \mathrm{C}$. When subjected to a severe fire greater than $14.5 \mathrm{MW}$, the recommended failure criterion is $500^{\circ} \mathrm{C}$.

- The critical heat flux required for failure was above $45 \mathrm{~kW} / \mathrm{m}^{2}$.

The heat flux at failure is not sensitive to the storage configuration and the magnitude of the fire. For predicting failures from exposure fires, the commonly used threshold radiant heat flux of $45 \mathrm{~kW} / \mathrm{m}^{2}$ appears to be low relative to the test data. Based on the analysis, a better estimate of the failure criterion is $68 \mathrm{~kW} / \mathrm{m}^{2}$.

- The failure rate for drums on pallets was $15 \%$.

The total number of failed drums on pallets, including those with failed seals, was twenty-two (22) as shown in Tables 9 and 11 in WHC-SD-WM-TRP-246 (Reference 1). The failure rate includes seal failures, which constitute $50 \%$ of the failed drums on pallets. Seal failures of drums would not result in a significant release. The total failure rate conservatively rounded up to $20 \%$ represents a bounding estimate of the drum failure in the source term calculation.

Application of the recommended criteria for the heat flux and the temperature in an exposure fire, those not engulfed in a fuel pool fire as in Figure 1, will yield an extremely conservative source term. Those in a fuel pool fire, application of the recommended criteria will yield a conservative source term. Hence, the recommended failure criteria will lead to a technically robust and defensible safety analysis that bounds the potential consequences from postulated fires in TRU waste storage facilities involving the Type A, 55-gal drums.

\section{References}

1. WHC-SD-WM-TRP-246, "Solid Waste Drum Array Fire Performance," Rev. 0, Westinghouse Hanford Company, 1995.

2. UCRL-MA-117541, “Cheetah 2.0 User's Manual," Rev. 5, Lawrence Livermore National Laboratory, L.E. Fried, August 1998.

3. The SFPE Handbook of Fire Protection Engineering, $2^{\text {nd }}$ ed., Society of Fire Protection Engineers, Boston, MA, 1996.

4. Probability and Statistics, Murray R. Spiegel, John Shiller, and R. Alu Srinivasan, Schaum's Outline, $2^{\text {nd }}$ edition, McGraw-Hill, 2000. 
Figure 5. Distribution of the number of failed drums at the measured heat flux with an interval of $10 \mathrm{~kW} / \mathrm{m}^{2}$ from the combined data.

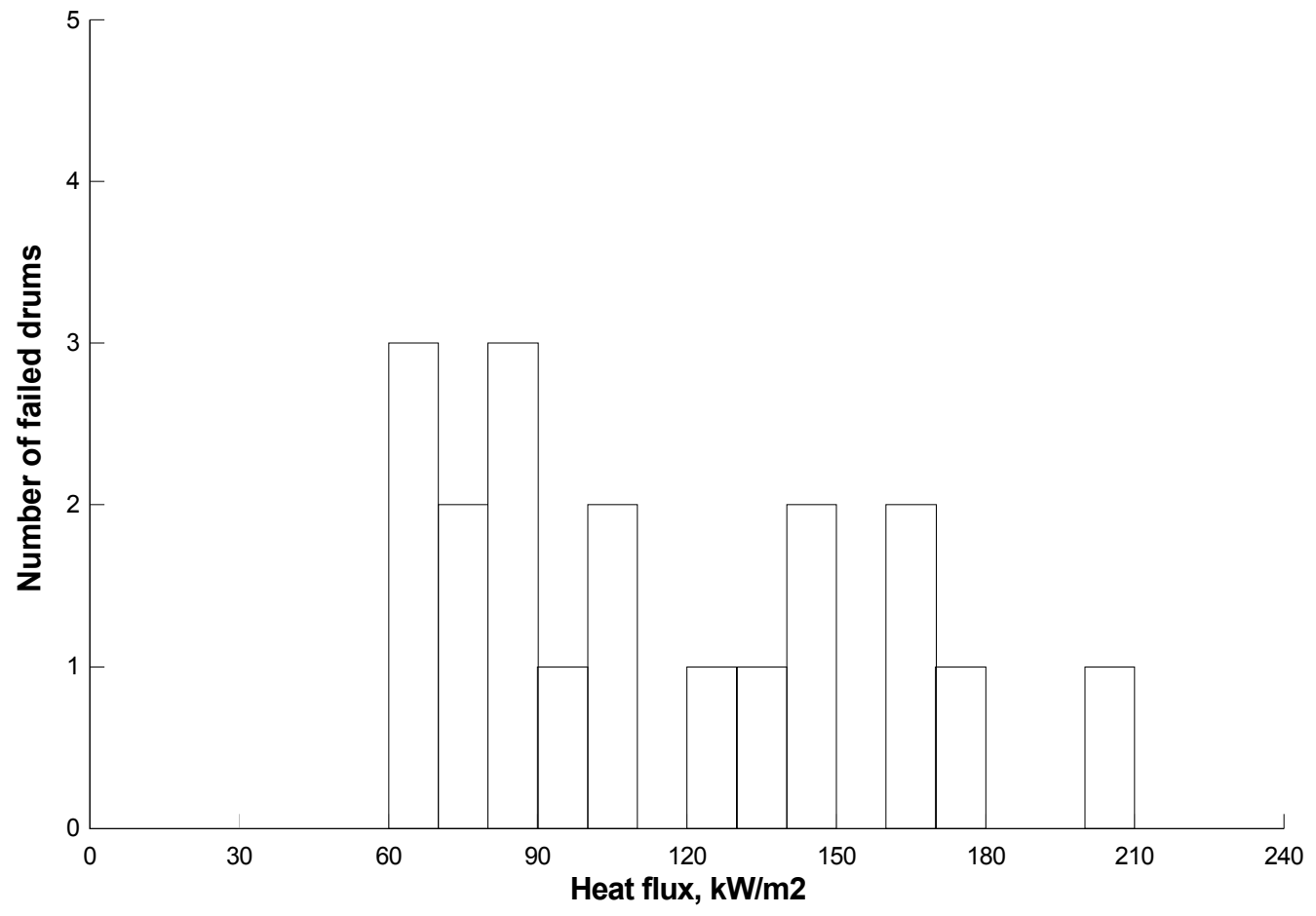

Figure 6. Distribution of the number of failed drums at the measured temperature with an interval of $50^{\circ} \mathrm{C}$ from the combined data.

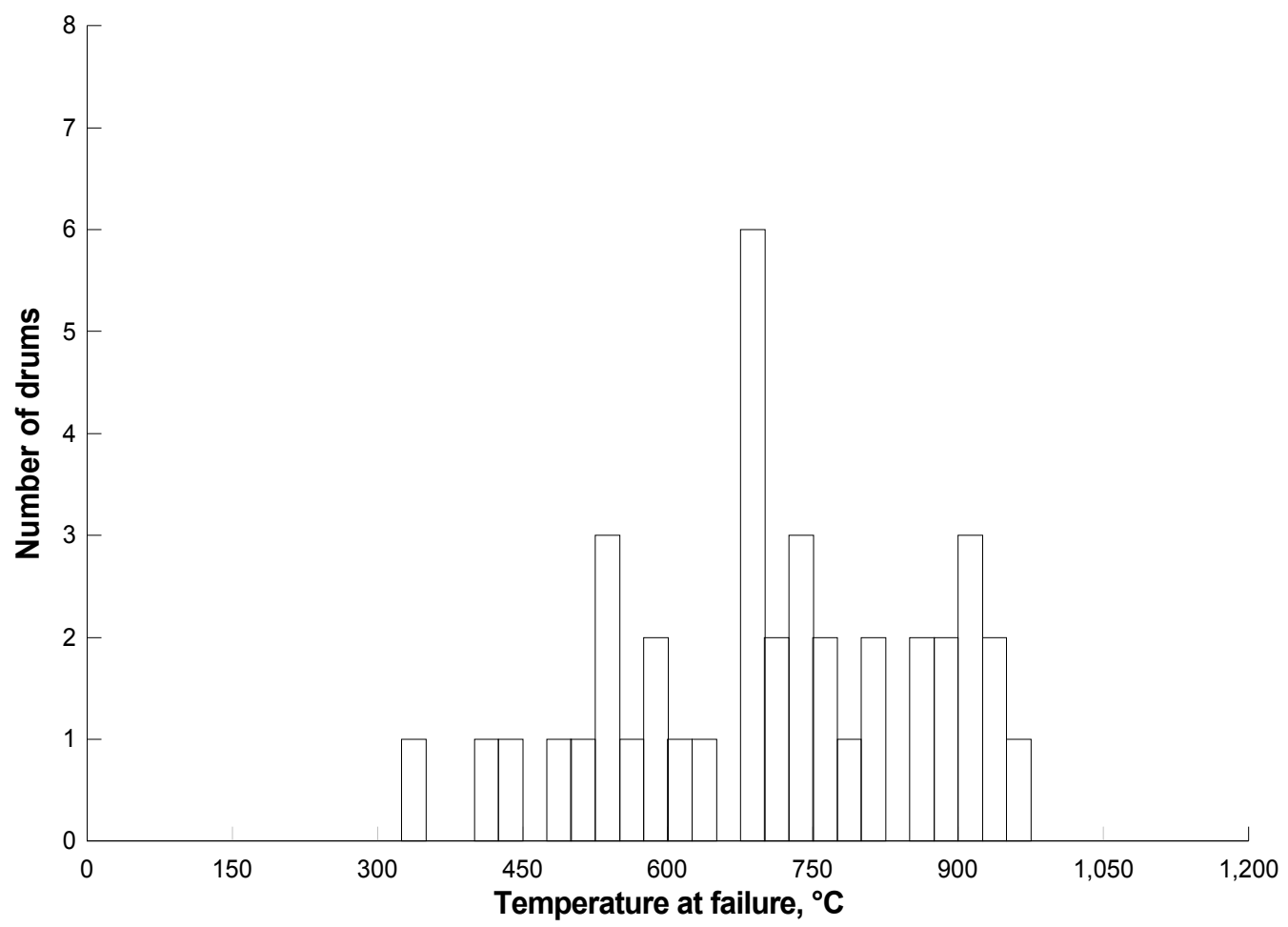


Re-evaluation of Hanford fire test data

UCRL-TR-230686

Table 1. Measured drum failure data from the combined rack storage configuration and pallet storage configuration tests.

\begin{tabular}{|c|c|c|c|c|c|c|c|c|}
\hline & Drum No. & Lid Loss or Rupture & Time, s & $\begin{array}{l}\text { Temperature, } \\
{ }^{\circ} \mathrm{C}\end{array}$ & $\begin{array}{l}\text { Pressure, } \\
\text { psig }\end{array}$ & $\begin{array}{l}\text { Heat flux, } \\
\mathrm{kW} / \mathrm{m}^{2}\end{array}$ & $\begin{array}{l}\text { Out of/ln } \\
\text { Flame }\end{array}$ & $\begin{array}{c}\text { Table } \\
\text { No. }^{\dagger}\end{array}$ \\
\hline 1 & 0521 & LID LOSS & 203 & 811 & 12.8 & 200 & Out & 11 \\
\hline 2 & O532 & VENT & 212 & 918 & 11.4 & 176 & Out & 11 \\
\hline 3 & O533 & VENT & 254 & 920 & 11.6 & 124 & Out & 11 \\
\hline 4 & O541 & VENT & 292 & 698 & 6.9 & $\mathrm{NM}^{*}$ & Out & 11 \\
\hline 5 & O611 & LID RUPTURE & 165 & 731 & 14.5 & NM & In & 9 \\
\hline 6 & O612 & VENT & 172 & 937 & 9.5 & NM & $\ln$ & 9| \\
\hline 7 & $\mathrm{O} 631$ & LID LOSS & 147 & 803 & 16.4 & 166 & $\ln$ & 9 \\
\hline 8 & $\mathrm{O} 632$ & LID RUPTURE & 156 & 876 & 17.3 & 135 & $\ln$ & 9 \\
\hline 9 & O633 & LID RUPTURE & 245 & 891 & 9.7 & 81 & $\ln$ & 9 \\
\hline 10 & $\mathrm{O} 641$ & LID RUPTURE & 197 & 699 & 8.9 & 77 & In & 9 \\
\hline 11 & $\mathrm{O} 711$ & LID RUPTURE & 159 & 732 & 14.0 & NM & In & 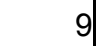 \\
\hline 12 & 0713 & VENT & 154 & 908 & 15.4 & NM & In & a \\
\hline 13 & $\mathrm{O} 721$ & VENT & 160 & 744 & 12.0 & NM & In & 9 \\
\hline 14 & $\mathrm{O} 722$ & VENT & 169 & 932 & 16.4 & NM & In & 9 \\
\hline 15 & $\mathrm{O} 723$ & LID RUPTURE & 185 & 759 & 11.6 & NM & In & 9 \\
\hline 16 & $\mathrm{O} 741$ & VENT & 195 & 600 & 3.1 & NM & In & 9 \\
\hline 17 & $\mathrm{O} 742$ & VENT & 518 & 778 & 8.6 & NM & In & 9 \\
\hline 18 & $\mathrm{O} 743$ & VENT & 763 & 526 & 6.4 & NM & In & 9 \\
\hline 19 & 0811 & LID RUPTURE & 156 & 857 & 11.3 & NM & Out & 11 \\
\hline 20 & O812 & LID RUPTURE & 152 & 851 & 17.4 & NM & Out & 11 \\
\hline 21 & O813 & LID RUPTURE & 175 & 951 & 14.6 & NM & Out & 11 \\
\hline 22 & O831 & VENT & 363 & 538 & 5.8 & 85 & Out & 11 \\
\hline 23 & $\mathrm{X} 122$ & VENT & 207 & 574 & 3.0 & 68 & Out & 8 \\
\hline 24 & $\mathrm{X} 123$ & VENT & 296 & 528 & 2.7 & 64 & Out & 8 \\
\hline 25 & $\mathrm{X} 125$ & VENT & 362 & 507 & 2.4 & NM & Out & 8 \\
\hline 26 & $\mathrm{X} 131$ & VENT & 166 & 592 & 5.2 & 95 & Out & 8 \\
\hline 27 & $\times 211$ & LID RUPTURE & 112 & 680 & 12.4 & NM & $\ln$ & 0 \\
\hline 28 & $X 213$ & LID LOSS & 119 & 427 & 11.0 & NM & $\ln$ & 6 \\
\hline 29 & $X 214$ & LID LOSS & 163 & 483 & 11.0 & NM & In & 6 \\
\hline 30 & $X 222$ & LID LOSS & 98 & 760 & 16.5 & 142 & $\ln$ & 6 \\
\hline 31 & $X 224$ & LID RUPTURE & 211 & 592 & 7.1 & 75 & In & 6 \\
\hline 32 & X225 & LID RUPTURE & 236 & 686 & 7.8 & 88 & In & 6 \\
\hline 33 & $\mathrm{X} 226$ & LID RUPTURE & 275 & 699 & 6.7 & 109 & In & 6 \\
\hline 34 & $\mathrm{X} 231$ & LID LOSS & 162 & 693 & 8.7 & 165 & In & 6 \\
\hline 35 & $\mathrm{X} 233$ & LID LOSS & 273 & 627 & 7.5 & 147 & In & 6 \\
\hline 36 & $X 256$ & VENT & 298 & 339 & 3.8 & NM & Out & 6 \\
\hline 37 & X312 & LID RUPTURE & 110 & 701 & 11.0 & NM & $\ln$ & 6 \\
\hline 38 & X321 & LID RUPTURE & 122 & 711 & 10.0 & 101 & In & 6 \\
\hline 39 & X332 & LID LOSS & 249 & 400 & 8.4 & 66 & In & 6 \\
\hline
\end{tabular}




\begin{tabular}{|c|crc|}
\hline $\bar{x}$ & 704.1 & 113.9 \\
$s^{2}$ & 25975 & 1,774 \\
$s$ & 161.2 & 42.12 \\
Sample size & 39 & 19 \\
$t(0.025)^{\star *}$ & 2.025 & 2.101 \\
$t(0.01)$ & 2.713 & 2.878 \\
& 651.8 & 93.59 \\
& Lower limit of the mean at $95 \% \mathrm{CL}$ & 86.08 \\
\hline
\end{tabular}

${ }^{\dagger}$ From Reference 1

* Not measured

** From Reference 4 